\title{
Ground vegetation composition and diversity in drained Norway spruce (Picea abies (L.) Karst.) stands 50 years after whole-tree harvesting management: case study in Latvia
}

\author{
Roberts Čakšs ${ }^{*}$, Linda Robalte, Iveta Desaine, Baiba Džeringa \\ and Aris Jansons
}

Čakšs, R., Robalte, L., Desaine, I., Džeringa, B., Jansons, A. 2018. Ground vegetation composition and diversity in drained Norway spruce (Picea abies (L.) Karst.) stands 50 years after whole-tree harvesting management: case study in Latvia. - Forestry Studies | Metsanduslikud Uurimused 69, 33-43. ISSN 14069954. Journal homepage: http:/ / mi.emu.ee/forestry.studies

\begin{abstract}
The long-term (50 years) effect of whole-tree harvesting (stump harvesting) on ground vegetation in experimental drained Norway spruce (Picea abies (L.) Karst.) stands was studied. We used a chronosequence approach to assess the long-term impact of whole-tree harvesting (WTH) on stands' ground vegetation. WTH stands were compared with four control stands with different age and with the same forest type: young stand (15 years), middle-aged stand (45 years), mature stand (110 years) and over-mature stand (140 years). Species richness was similar between the WTH stand and middle-aged stand (61 and 60 species, respectively). Shannon-Wiener diversity indices in the WTH and middle-aged stand (3.40 and 3.19 , respectively) indicated that the stands were similar to each other. A community similarity analysis showed that the composition of vegetation was similar between the WTH and middle-aged stand, although some species like Lycopodium clavatum and Diphasiastrum complanatum occurred only in the WTH stand. The study showed that a period of 50 years is sufficient for ground vegetation of a typical drained spruce forest to recover after WTH management.
\end{abstract}

Key words: biomass removal, stump harvesting, ground vegetation regeneration.

Authors' addresses: Latvian State Forest Research Institute "Silava”, Rigas 111, Salaspils, Latvia, LV-2169; *e-mail: cakss.roberts@gmail.com

\section{Introduction}

The demand for renewable energy has been growing exponentially (Egnell, 2011). Means for effective use of wood resources for renewable energy in the future (Walmsley et al., 2009) include whole-tree harvesting (WTH) forest management, whereby all tree logging residuals (as well as stumps) are removed from logged stands
(Egnell \& Leijon, 1997). Harvested residues and stumps can add up to $25 \%$ more resources for production of energy (Hakkila, 2004). The largest part of Norway spruce (Picea abies (L.) Karst.) stands has been planted for commercial forestry, and presently spruce is one of the most common tree species in hemiboreal forests (Rytter et al., 2013). In Latvia, ca $21 \%$ of all the forest land area is covered by spruce-dominated 
stands, and $8 \%$ of these stands have been drained, i.e. $38 \%$ of spruce-dominated forests are drained (according to data from the National Forest Inventory). Drained spruce stands are mesotrophic forests in which ground vegetation and mineral soils after draining become more similar to those in conditions of a regular moisture regime (Bušs, 1976). The development of ground vegetation in spruce forests is determined by the composition and quantity of mineral elements and the amount of light (Kubin, 1983; Kolstad et al., 2016). The diversity of vascular plants and bryophyte species in hemiboreal coniferous forests is an important component of forest ecosystems (Nilsson \& Wardle, 2005). Recent studies on the recovery of soil and vegetation 8-31 years after WTH management in Sweden and Finland spruce forests have shown contrasting results: some studies showed a significant decrease in the concentration of mineral elements after WTH management (Egnell, 2011), while others did not find a significant effect on ground vegetation and soil mineral element composition (Egnell et al., 2015; Hyvönen et al., 2016). Another study showed that WTH management in spruce stands can result in changes in the ground cover species composition (Saksa, 2013). Current knowledge on the impact of WTH on the composition and richness of ground vegetation in mesotrophic forest stands is insufficient.

The aim of this study was to reveal potential long-term (50 years) influences of WTH management on the composition of ground vegetation in Norway spruce stands, which is a period much longer than in other studies (Egnell \& Leijon, 1997; Hyvönen et al., 2016). The vegetation was compared to that of other commercial spruce stands which had been harvested by conventional means. We hypothesized that WTH had a long-term effect on the composition and richness of ground vegetation, and that characteristic species of spruce forests were replaced by oligotrophic forest species and pioneer species.

\section{Materials and Methods}

\section{Study site and sampling}

The study was carried out in the eastern part of Latvia $\left(56^{\circ} 68^{\prime} \mathrm{N}, 2^{\circ} 99^{\prime} \mathrm{E}\right)$ in planted Norway spruce forest stands on drained mineral soil. The mean monthly temperature from 1981 to 2016 in this region was $17.9^{\circ} \mathrm{C}$ in July and $-4.4^{\circ} \mathrm{C}$ in January, and average precipitation was $553 \mathrm{~mm}$. The topography was flat (Nikodemus et al., 2018).

We used the chronosequence approach to assess the long-term impact of WTH on ground vegetation. One forest stand (6 ha) with WTH management after clear-cut harvesting in 1968 was compared with four conventionally managed control stands with different age: a young stand (15 years), middle-aged stand (45 years - similar age to the stand with WTH treatment), mature stand (110 years) and over-mature stand (140 years). 


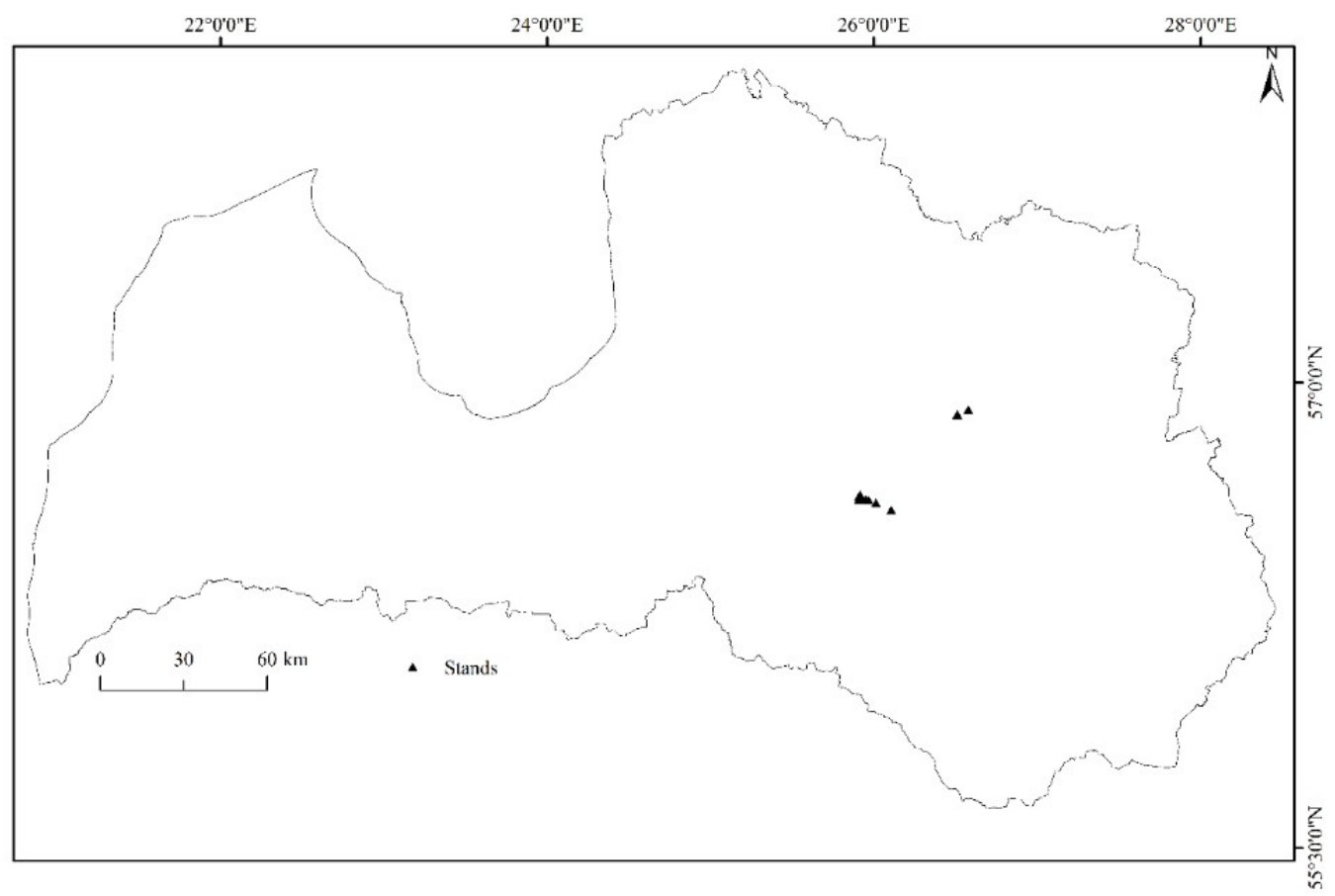

Figure 1. Map of Latvia with stand locations.

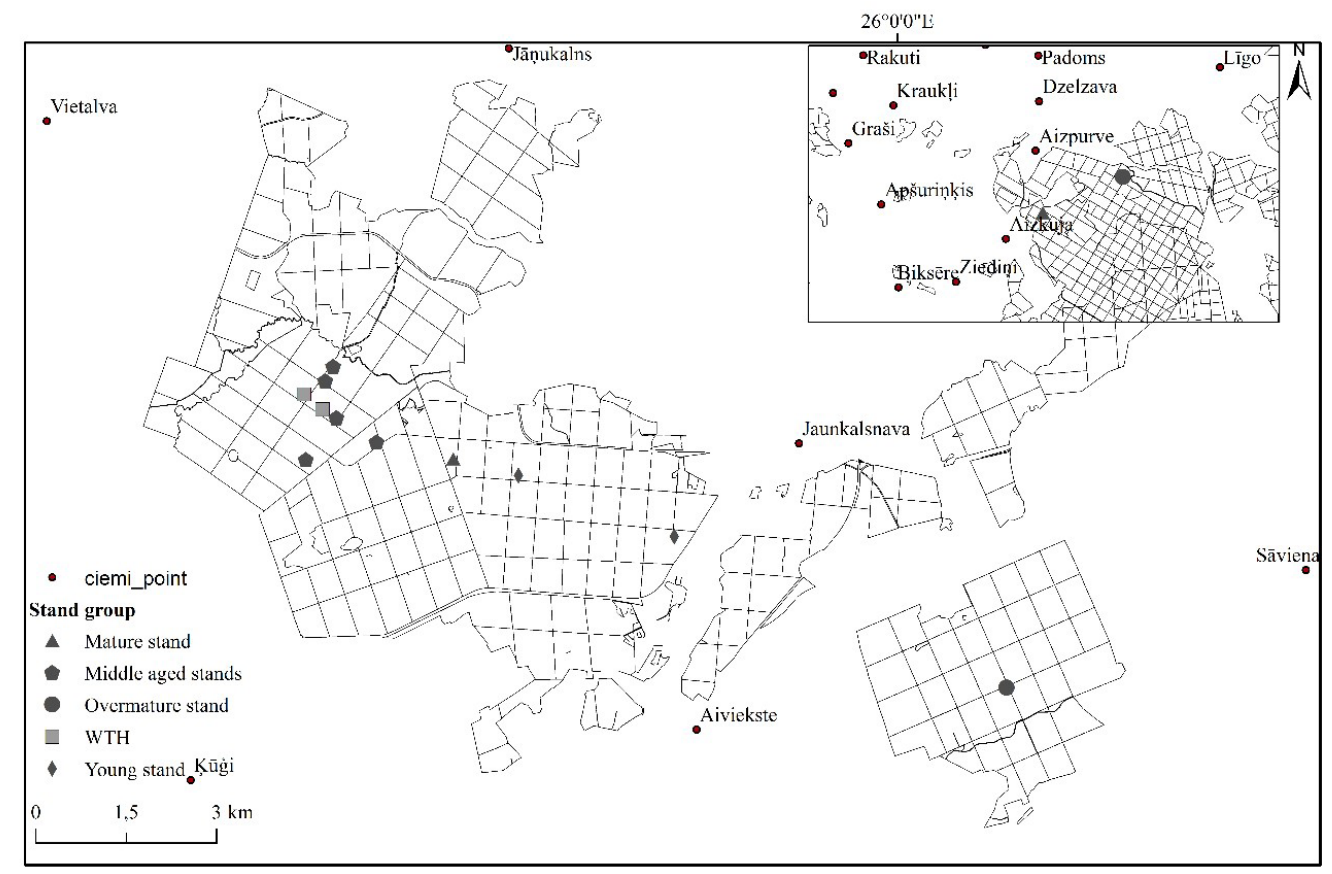

Figure 2. Map of stand locations in the Forest Research Station in Kalsnava 
Ground vegetation was assessed visually in $1 \times 1 \mathrm{~m}$ sample plots that were regularly placed on transects (distance between plots was $2 \mathrm{~m}$; 289 sample plots were established). In total, 17 transects with 17 sample plots, with a length of $50 \mathrm{~m}$ were established: two transects per stand in the young and mature stand, and five and six transects in the WTH and middle-aged stand, respectively. In each plot, we assessed the cover $(\%)$ of each species and the total cover of vascular plants and bryophyte species and it was described in two layers: the ground layer with mosses and bare soil and the vascular plant layer.

\section{Data analysis}

Mean Shannon $\left(H^{\prime}\right)$ and Simpson's $(D)$ diversity indices (Krebs, 2014) were calculated for each stand. We used both indices because Shannon indices show species diversity, but Simpson's indices show evenness and richness. The t-test was used to test for significant differences in the relative cover of the vascular plants and bryophyte species between stands, as sample sizes on groups were unequal, the $t$-test with Welch adjustments was used. We calculated the mean relative cover for each species in each stand to show how common they were. An analysis of similarities (ANOSIM) was used on stand level to compare vegetation between forest stands (WTH, middle-aged stand, young stand, mature stand, over-mature stand). The analysis shows $R$ values which differ from 0 to 1 , as the value is closer to 0 the more similar territories we have, if the value is closer to 1 the more different the stands are (Clarke, 1993). NMS (Non-metric multidimensional scaling) was used to visualize trends of change in vegetation composition; the results of the DCA (detrended correspondence analysis) were similar to NMS. The analyses were carried out in the program
$R$ version 3.4.2. (R Core Team, 2017), using the package vegan (Oksanen et al., 2013).

\section{Results}

The highest mean cover (\%) of vascular plants and mosses occurred in the mature stand $(44.4 \%$ and $94.7 \%$, respectively) and over-mature stand $(26.4 \%$ and $94.1 \%$, respectively) (Table 1). The mean cover of vascular plant species and mosses was lower in the middle-aged $(5.1 \%, 78.3 \%$, respectively) and WTH stand (10.3\%, $81.3 \%$, respectively) (Table 1). In each forest stand, the cover of a particular vascular plant species did not exceed $20 \%$, whereas the moss layer frequently had dominant species, with the cover of one species reaching $47 \%$. Species richness was lower in the oldest stands (over-mature and mature), and higher in the WTH and middle-aged stand (61 and 60 species, respectively).

The most common vascular plant species in the WTH and middle-aged stand were Luzula pilosa $(1.5 \%$ and $0.6 \%$, respectively) and Oxalis acetosella (1.1\% and $0.5 \%$, respectively) (Table 2A). In all forest stands moss species were dominant with a $83.9 \%$ mean relative cover. Feather mosses were the dominant species in all stands, and the highest cover of Pleurozium schreberi and Hylocomium splendens occurred in the mature stand $(47.4 \%$ and $20.2 \%$, respectively) (Table 2). The moss species Plagiomnium affine, Plagiomnium elipticum and Rhodobryum roseum were most common in the WTH and middle-aged stand (Table 2B).

Species diversity had no significant differences (Shannon-Wiener diversity index) and it was higher in the WTH stand (3.40), lowest in the over-mature stand (2.18), and $\sim 3.16$ in the other stands (Table 1). Simpson's diversity was, also, lowest in the over-mature stand (0.87) and $\sim 0.94$ in the other stands (Table 2A). 
Table 1. Shannon and Simpson's diversity indices for ground vegetation. Mean cover is given for the vascular plant and bryophyte layers. Data is from experimental plots in a drained Norway spruce stand where all biomass was removed (WTH; 50 years), and conventionally managed stands: a middle-aged stand with similar age (45 years), young stand (15 years), mature stand (110 years) and over-mature stand (140 years). $\mathrm{N}$ - number of sample plots.

\begin{tabular}{|c|c|c|c|c|c|}
\hline & $\begin{array}{c}\text { WTH } \\
(\mathrm{N}=85)\end{array}$ & $\begin{array}{l}\text { Middle-aged stand } \\
\quad(\mathrm{N}=102)\end{array}$ & $\begin{array}{l}\text { Young stand } \\
\qquad(\mathrm{N}=34)\end{array}$ & $\begin{array}{l}\text { Mature stand } \\
\quad(\mathrm{N}=34)\end{array}$ & $\begin{array}{l}\text { Over-mature } \\
\text { stand }(\mathrm{N}=34)\end{array}$ \\
\hline Shannon & 3.40 & 3.19 & 3.16 & 3.12 & 2.18 \\
\hline $\begin{array}{l}\text { Shannon standard } \\
\text { deviation }\end{array}$ & 0.057629 & 0.064487 & 0.065093 & 0.055467 & 0.113487 \\
\hline Simpson & 0.95 & 0.93 & 0.94 & 0.95 & 0.87 \\
\hline Vascular plant cover (\%) & 10.3 & 5.1 & 10.8 & 44.4 & 26.4 \\
\hline Bryophyte cover (\%) & 81.3 & 78.3 & 71.1 & 94.7 & 94.1 \\
\hline
\end{tabular}

Table 2A. Mean relative cover (\%) of vascular plant species. Data is from experimental plots in a drained Norway spruce stand where all biomass was removed (WTH; 50 years), and conventionally managed stands: a middle-aged stand with similar age (45 years), young stand (15 years), mature stand (110 years) and over-mature stand (140 years). $\mathrm{N}$ - number of sample plots.

\begin{tabular}{|c|c|c|c|c|c|c|}
\hline & $\begin{array}{l}\text { Abbrevi- } \\
\text { ations }\end{array}$ & $\begin{array}{c}\text { WTH } \\
(\mathrm{N}=85)\end{array}$ & $\begin{array}{l}\text { Middle- } \\
\text { aged stand } \\
(\mathrm{N}=102)\end{array}$ & $\begin{array}{l}\text { Young } \\
\text { stand } \\
(\mathrm{N}=34)\end{array}$ & $\begin{array}{l}\text { Mature } \\
\text { stand } \\
(\mathrm{N}=34)\end{array}$ & $\begin{array}{c}\text { Over- } \\
\text { mature } \\
\text { stand } \\
(\mathrm{N}=34)\end{array}$ \\
\hline Anemone nemorosa & Anenem & 1.27 & 0.32 & 0 & 0 & 0 \\
\hline Anemone ranunculoides & Aneran & 0 & 0.03 & 0 & 0 & 0 \\
\hline Angelica sylvestris & Angsyl & 0.13 & 0.03 & 0.06 & 0 & 0 \\
\hline Athyrium filix-femina & Athfil & 0 & 0 & 0.15 & 0 & 0 \\
\hline Stellaria nemorum & Stenem & 0.11 & 0.46 & 0 & 0 & 0 \\
\hline Calamagrostis arundinacea & Calaru & 0.6 & 0 & 1.76 & 3.47 & 0 \\
\hline Calamagrostis canescens & Calcan & 0 & 0.02 & 0 & 0 & 0 \\
\hline Carex digitata & Cardig & 0 & 0 & 0.44 & 1.68 & 0 \\
\hline Carex pallescens & Carpal & 0 & 0 & 0 & 0.5 & 0 \\
\hline Carex sp. & Carsp. & 0.64 & 0.05 & 0.88 & 0.26 & 0.03 \\
\hline $\begin{array}{l}\text { Chamaenerion } \\
\text { angustifolium }\end{array}$ & Chaang & 0.06 & 0 & 0 & 0 & 0 \\
\hline Cirsium sp. & Cirsp. & 0 & 0 & 0.06 & 0.06 & 0 \\
\hline Convallaria majalis & Conmaj & 0 & 0 & 0.38 & 0 & 0 \\
\hline Coronaria flos-cuculi & Corflo & 0.04 & 0 & 0 & 0 & 0 \\
\hline Dactylis glomerata & Dacglo & 0 & 0.01 & 0 & 0 & 0 \\
\hline Deschampsia caespitosa & Descae & 0.06 & 0 & 0 & 0.44 & 0 \\
\hline Deschampsia flexuosa & Desfle & 0.19 & 0.02 & 0.09 & 0 & 0 \\
\hline $\begin{array}{l}\text { Diphasiastrum } \\
\text { complanatum }\end{array}$ & Dipcom & 0.24 & 0 & 0 & 0 & 0 \\
\hline Dryopteris carthusiana & Drycar & 0.18 & 0.42 & 0.35 & 0.53 & 0 \\
\hline Epilobium palustre & Epipal & 0.09 & 0.07 & 0.35 & 0.03 & 0 \\
\hline Epipactis sp. & Episp. & 0 & 0 & 0 & 0.03 & 0 \\
\hline
\end{tabular}




\begin{tabular}{|c|c|c|c|c|c|c|}
\hline & $\begin{array}{l}\text { Abbrevi- } \\
\text { ations }\end{array}$ & $\begin{array}{c}\text { WTH } \\
(\mathrm{N}=85)\end{array}$ & $\begin{array}{l}\text { Middle- } \\
\text { aged stand } \\
(\mathrm{N}=102)\end{array}$ & $\begin{array}{l}\text { Young } \\
\text { stand } \\
(\mathrm{N}=34)\end{array}$ & $\begin{array}{l}\text { Mature } \\
\text { stand } \\
(\mathrm{N}=34)\end{array}$ & $\begin{array}{c}\text { Over- } \\
\text { mature } \\
\text { stand } \\
(\mathrm{N}=34)\end{array}$ \\
\hline Equisetum pratense & Equpra & 0 & 0 & 0 & 0.29 & 0 \\
\hline Equisetum sylvaticum & Equsyl & 0.14 & 0 & 0.03 & 0.41 & 0 \\
\hline Filipendula ulmaria & Filulm & 0.02 & 0 & 0 & 0 & 0 \\
\hline Fragaria vesca & Fraves & 0.21 & 0 & 0 & 0.32 & 0 \\
\hline Galeobdon luteum & Gallut & 0 & 0 & 0.21 & 0.56 & 0 \\
\hline Gallium aparine & Galapa & 0.02 & 0 & 0 & 0 & 0 \\
\hline Galium mollugo & Galmol & 0.13 & 0 & 0 & 0 & 0 \\
\hline Galium palustre & Galpal & 0 & 0.01 & 0 & 0 & 0 \\
\hline Galium uliginosum & Galuli & 0 & 0 & 0.03 & 0 & 0 \\
\hline Gallium album & Galalb & 0 & 0 & 0.06 & 0 & 0 \\
\hline Galeopsis ladanum & Gallad & 0 & 0.03 & 0 & 0 & 0 \\
\hline Luzula pilosa & Luzpil & 1.56 & 0.65 & 1.74 & 2.29 & 0 \\
\hline Lycopodium annotinum & Lycann & 0.06 & 0.05 & 0 & 0.35 & 0 \\
\hline Lycopodium clavatum & Lyccla & 0.06 & 0 & 0 & 0 & 0 \\
\hline Lysimachia vulgaris & Lysvul & 0.35 & 0.09 & 0 & 0.15 & 0 \\
\hline Maianthemum bifolium & Maibif & 0.64 & 0.09 & 0.03 & 0.59 & 0 \\
\hline Hieracium pilosella & Hiepil & 0 & 0 & 0.03 & 0 & 0 \\
\hline Melampyrum pratense & Melpra & 0.02 & 0.01 & 0 & 0.03 & 0 \\
\hline Melica nutans & Melnut & 0 & 0 & 0 & 0.32 & 0 \\
\hline Molinia caerulea & Molcae & 0 & 0.2 & 0 & 0 & 0 \\
\hline Moneses uniflora & Monuni & 0.12 & 0 & 0 & 0 & 0 \\
\hline Mycelis muralis & Mycmur & 0.08 & 0.05 & 0 & 0.32 & 0 \\
\hline Myosotis sylvatica & Myosyl & 0.01 & 0 & 0 & 0 & 0 \\
\hline Oxalis acetosella & Oxaace & 0.96 & 0.55 & 0.38 & 10.44 & 0 \\
\hline Orthilia secunda & Ortsec & 0.62 & 0.04 & 0.03 & 0.38 & 0 \\
\hline Galeopsis tetrahit & Galtet & 0 & 0.07 & 0 & 0 & 0 \\
\hline Paris quadrifolia & Parqua & 0.01 & 0.01 & 0.09 & 0 & 0 \\
\hline Phragmites australis & Phraus & 0.02 & 0.01 & 0 & 0 & 0 \\
\hline Poa nemoralis & Poanem & 0.14 & 0.05 & 0 & 0 & 0 \\
\hline Poa palustris & Poapal & 0.13 & 0.01 & 0 & 0 & 0 \\
\hline Potentilla erecta & Potere & 0.16 & 0.01 & 0 & 0 & 0 \\
\hline Pteridium aquilinium & Pteaqu & 0 & 0 & 0.35 & 0 & 0 \\
\hline Rubus idaeus & Rubida & 0.02 & 0.09 & 0 & 0.09 & 0 \\
\hline Rubus saxatilis & Rubsax & 0.29 & 0.02 & 0 & 1.06 & 0 \\
\hline Solidago virgaurea & Solvir & 0.35 & 0.04 & 0.06 & 0.76 & 0 \\
\hline Trientalis europea & Trieur & 0.01 & 0 & 0 & 0.91 & 0 \\
\hline Urtica dioica & Urtdio & 0 & 0.07 & 0 & 0 & 0 \\
\hline Vaccinium myrtillus & Vacmyr & 0.06 & 0.07 & 2.06 & 15.59 & 18.59 \\
\hline Vaccinium uliginosum & Vaculi & 0 & 0.92 & 0 & 0 & 0 \\
\hline Vaccinium vitis-idea & Vacvit & 0.04 & 0.05 & 0.35 & 2.44 & 7.82 \\
\hline Veronica chamaedris & Vercha & 0.07 & 0.23 & 0 & 0 & 0 \\
\hline Veronica officinalis & Veroff & 0.2 & 0.01 & 0.15 & 0 & 0 \\
\hline Viola canina & Viocan & 0.02 & 0 & 0 & 0 & 0 \\
\hline Viola sp. & Viosp. & 0.22 & 0.36 & 0.68 & 0.12 & 0 \\
\hline
\end{tabular}


Table 2B. Mean relative cover (\%) of bryophyte species. Data is from experimental plots in a drained Norway spruce stand where all biomass was removed (WTH; 50 years), and conventionally managed stands: a middle-aged stand with similar age (45 years), young stand (15 years), mature stand (110 years) and over-mature stand (140 years). $\mathrm{N}$ - number of sample plots.

\begin{tabular}{|c|c|c|c|c|c|c|}
\hline & $\begin{array}{l}\text { Abbrevi- } \\
\text { ations }\end{array}$ & WTH & $\begin{array}{l}\text { Middle- } \\
\text { aged stand } \\
(\mathrm{N}=102)\end{array}$ & $\begin{array}{l}\text { Young } \\
\text { stand } \\
(\mathrm{N}=34)\end{array}$ & $\begin{array}{l}\text { Mature } \\
\text { stand } \\
(\mathrm{N}=34)\end{array}$ & $\begin{array}{l}\text { Over-mature } \\
\text { stand }(\mathrm{N}=34)\end{array}$ \\
\hline Atrichum undulatum & Atrund & 0.99 & 0.02 & 0 & 0 & 0 \\
\hline Aulacomnium palustre & Aulpal & 0.08 & 0.08 & 0 & 0 & 0 \\
\hline Bruym sp. & Brusp. & 0.78 & 2.64 & 0 & 0 & 0 \\
\hline Cirriphyllum piliferum & Cirpil & 3.56 & 0.31 & 0 & 0 & 0.03 \\
\hline Climacium dendroides & Cliden & 0 & 0 & 0.15 & 0 & 0 \\
\hline Dicranum majus & Dicmaj & 0 & 1.02 & 0 & 0.06 & 0.09 \\
\hline Dicranum polysetum & Dicpol & 4.18 & 4.51 & 7.68 & 6.85 & 4.91 \\
\hline Dicranum scoparium & Dicsco & 3.4 & 1 & 0 & 0.06 & 0.44 \\
\hline Eurhynchium angustirete & Eurang & 0 & 1.52 & 1.47 & 0 & 0 \\
\hline Hylocomium splendens & Hylspl & 20.55 & 11.06 & 18.26 & 20.21 & 32.35 \\
\hline Oxyrrhynchium hians & Oxyhia & 0.31 & 2.40 & 3.97 & 2.15 & 1.03 \\
\hline Plagiochila asplenoides & Plaasp & 0.12 & 0.55 & 0 & 7.65 & 0 \\
\hline Plagiomnium affine & Plaaff & 5.33 & 10.39 & 6.79 & 0.82 & 0 \\
\hline Plagiomnium cuspidatum & Placus & 0 & 0.03 & 0 & 0 & 0 \\
\hline Plagiomnium elipticum & Plaeli & 8.6 & 10.09 & 3.18 & 0.06 & 0 \\
\hline Plagiomnium undulatum & Plaund & 0 & 0.26 & 0 & 0 & 0 \\
\hline Pleurozim schreberi & Plesch & 26.26 & 25.94 & 22.44 & 47.21 & 19.71 \\
\hline Polyrtichum commune & Polcom & 0.41 & 1.23 & 0.18 & 0.29 & 21.32 \\
\hline $\begin{array}{l}\text { Pseudoscleropodium } \\
\text { purum }\end{array}$ & Psepur & 0.2 & 0 & 0 & 0 & 0 \\
\hline Ptilium crista-casstrensis & Pticri & 4.15 & 1.36 & 4.85 & 0 & 0 \\
\hline Rhodobryum roseum & Rhoros & 2.11 & 2.95 & 1.24 & 4.41 & 0 \\
\hline $\begin{array}{l}\text { Rhytidiadelphus } \\
\text { squarrosus }\end{array}$ & Rhysqu & 0 & 0.09 & 0 & 0 & 0.06 \\
\hline $\begin{array}{l}\text { Rhytidiadelphus } \\
\text { triquetrus }\end{array}$ & Rhytri & 0.31 & 0.2 & 0.91 & 3.47 & 0 \\
\hline Sphagnum girgensohnii & Sphgir & 0 & 0.33 & 0 & 1.32 & 10.76 \\
\hline Sphagnum squarrosum & Sphsqu & 0 & 0.30 & 0 & 0.15 & 3.41 \\
\hline
\end{tabular}

Table 3. Similarity in vegetation composition (ANOSIM R values) between pairs of a drained Norway spruce stand where all biomass was removed (WTH; 50 years), and conventionally managed stands: a middle-aged stand with similar age ( 45 years), young stand (15 years), mature stand (110 years) and over-mature stand (140 years). $\mathrm{N}$ - number of sample plots $(p<0.05)$.

\begin{tabular}{lcccc}
\hline & $\begin{array}{c}\text { Middle-aged stand } \\
(\mathrm{N}=102)\end{array}$ & $\begin{array}{c}\text { Young stand } \\
(\mathrm{N}=34)\end{array}$ & $\begin{array}{c}\text { Mature stand } \\
(\mathrm{N}=34)\end{array}$ & $\begin{array}{c}\text { Over-mature stand } \\
(\mathrm{N}=34)\end{array}$ \\
\hline WTH $(\mathrm{N}=85)$ & 0.03 & 0.07 & 0.15 & 0.37 \\
Middle-aged stand & & 0.02 & 0.09 & 0.33 \\
Young stand & & & 0.34 & 0.47 \\
Mature stand & & & & 0.38 \\
\hline
\end{tabular}


Table 4. Mean height, basal area and tree diameter are shown in the table. Data is from experimental plots in a drained Norway spruce stand where all biomass was removed (WTH; 50 years), and conventionally managed stands: a middle-aged stand with similar age (45 years), young stand (15 years), mature stand (110 years) and over-mature stand (140 years). $\mathrm{N}$ - number of sample plots.

\begin{tabular}{cccc}
\hline Stand & Mean height $(\mathrm{m})$ & Basal area & Mean tree diameter $(\mathrm{cm})$ \\
\hline WTH & 20 & 31 & 21 \\
Young stand & 9 & 8 & 7 \\
Middle-aged stand & 19 & 31 & 19 \\
Mature stand & 22 & 18 & 25 \\
Over-mature stand & 28 & 35 & 33 \\
\hline
\end{tabular}

The analysis of similarities (ANOSIM) showed that ground vegetation significantly differed between all pairs of forest stands ( $\mathrm{p}$-value $<0.001)$, although the highest similarity (lowest $R$ value - the test statistic) in vegetation composition occurred between the WTH and middle-aged stand $(R=0.03)$, and between the WTH and young stand $(R=0.07)$ (Table 3$)$. The highest dissimilarity from the WTH stand occurred between the over-mature and WTH stand $(\mathrm{R}=0.37)$ and over-mature and middle-aged stand $(\mathrm{R}=0.33)$.

The gradients in vegetation composition in the NMS ordination showed separation of the over-mature stand on the right side of the ordination and a considerable overlap of the other stands (WTH, middle-aged, young and mature stand) in the central part (Figure 3). Thus, the ordination gradient along the first axis appears to be associated with the succession gradient overlapping with the fertility/ disturbance gradient, with species of rich disturbed habitats early in succession, e.g. Urtica dioica, on the right side of ordination, to the older stands with a higher cover of, for example, Vaccinium species, on the left side. The second axis indicates that higher values refer to drier soils.

\section{Discussion}

Vascular plant cover in spruce-dominated forest stands mostly is negligible (5.1-
$44.4 \%$ ) (Vellak et al., 2003). The growth conditions in spruce stands are more suitable for mosses, but the growth conditions are altered after forest management and disturbances (Vanha-Majamaa et al., 2017), especially in younger planted stands (Saetre et al., 1997). Plant community composition and richness were similar between the WTH and middle-aged stand, and possibly 50 years of succession after disturbances is sufficient to develop a community of typical forest plant species. The results of our study confirm the well-known trend of an increasing vascular plant cover with stand age (Hart \& Chen, 2008).

In the WTH and middle-aged stand the dominant plants were Luzula pilosa and Oxalis acetosella, which are typical vascular plants of spruce forest stands (Packham, 1978; Uotila \& Kouki, 2005). These species occurred almost in all of the forest stands. A low vascular plant cover might be explained by a dense bryophyte layer on the forest floor, which delays plant development in spruce forest stands (Sirén, 1955), or by poor light conditions (Barbier et al., 2008).

Mosses are the dominant species in spruce stands (Hart \& Chen, 2008). In our study the cover of mosses was the highest in the mature, over-mature and WTH stand, which might be explained by a more closed canopy than in the mature and over-mature stand (Kneeshaw \& Bergeron, 1998). Among mosses, Pleurozium schreberi and Hylocomium splendens can easily occu- 


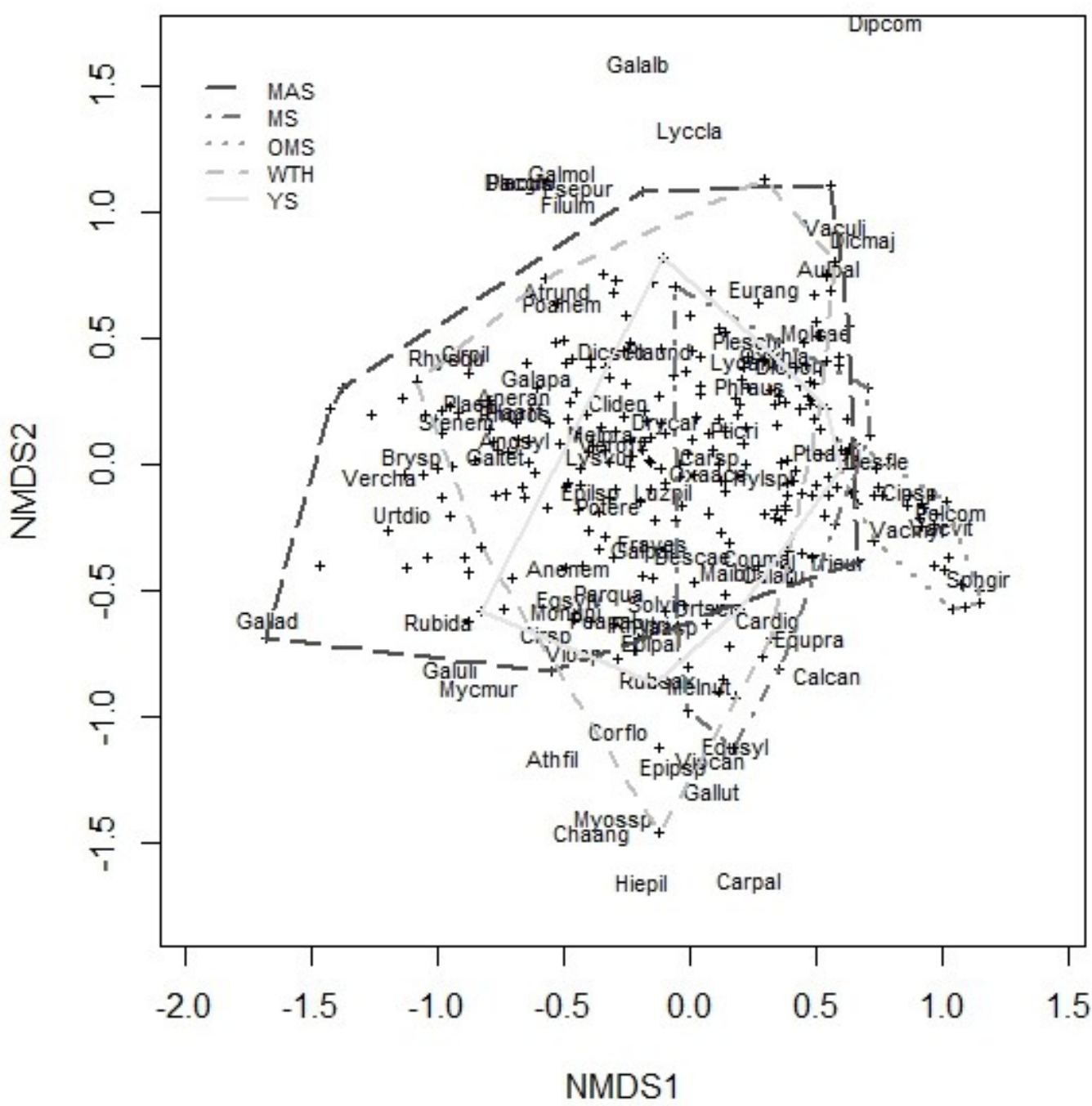

Figure 3. Detrended correspondence analysis (NMS) ordination of ground vegetation in the studied experimental drained Norway spruce stands. The lines drawn around groups of plots represent the standard deviations of the group (stand) centroids (directions of the principal axes are defined by weighted correlations). Data is from experimental plots in a drained Norway spruce stand where all biomass was removed as well as understorey vegetation (WTH; 50 years), and conventionally managed stands: a middle-aged stand with similar age (MAS; 45 years), young stand (YS; 15 years), mature stand (MS; 110 years) and over-mature stand (OMS; 140 years).

py the space of other mosses and outgrow them in forests where disturbances have been lacking for a long time (Jonsson \& Essen, 1990).

The Shannon-Wiener diversity index was the highest (3.40) in the WTH stand, which can be explained by ground dis- turbance allowing rapid development of ground vegetation (Luzuriaga et al., 2005). The high diversity index (3.19) in the middle-aged stand might indicate that the effect of WTH forest management on ground vegetation diversity is similar to that of conventional harvesting. Also, the com- 
position of ground vegetation in the WTH stand and middle-aged stand was typical of mesotrophic spruce stands (Engelmark \& Hytteborn, 1999). Characteristic species indicate favourable growth conditions in WTH forest stands (Bušs, 1976). For example, Plagiomnium spp. are the first colonizers in spruce forests after disturbances and are common in spruce forest stands (Cronberg et al., 2005). Simpson's evenness indices were similar among stands, except for the over-mature stand, which indicates a rather similar biological diversity in these stands (Hart \& Chen, 2008).

The analysis of similarity (ANOSIM) also showed a close similarity in vegetation composition between the WTH, middle-aged and young stand, while composition of these stands differed from that of the mature and over-mature stand. The ground vegetation in mature forests might have been affected by natural disturbances, typically wind (Angelstam \& Kuuluvainen, 2004), or by draining of the stands in the 1960s.

A large overlap of plots from the WTH, middle-aged and young stand in the NMS ordination is obvious, which also indicates similarities between these stands. The gradient along the first axis was associated with succession to older forests with more stable growth conditions (Ellenberg, 1988; Miles, 1985). The younger stands supported species that require more fertile growth conditions. Over time resources become limited in succession (Grime, 2006), explaining the differences in species composition of the older stands. The similar vegetation composition of the young and middle-aged stand might be explained by similar microsite conditions between 15 and 45-year-old stands.

\section{Conclusions}

Contrary to the initial hypothesis, WTH had a long-term effect on the composition and diversity of ground vegetation.
The stage of natural succession of ground vegetation was similar between the stands with WTH and conventional management at the same age of trees.

Acknowledgments. The study was supported by the joint stock company "Latvijas valsts meži" project "Impact of forest management on forest and related ecosystem services". We also acknowledge Didzis Elferts for suggestions in data analysis.

\section{References}

Angelstam, P., Kuuluvainen, T. 2004. Boreal forest disturbance regimes, successional dynamics and landscape structures - a European perspective. - Ecological Bulletins, 51, 117-136.

Barbier, S., Gosselin, F., Balandier, P. 2008. Influence of tree species on understory vegetation diversity and mechanisms involved - A critical review for temperate and boreal forests. - Forest Ecology and Management, 254, 1-15. https://doi.org/10.1016/j. foreco.2007.09.038.

Bušs, K. 1976. Basis of forest classification in SSR of Latvia. LRZTIPI, Riga. 73 p. (In Latvian).

Clarke, K.R. 1993. Non-parametric multivariate analysis of changes in community structure. Australian Journal of Ecology, 18(1), 117-143. https:// doi.org/10.1111/j.1442-9993.1993. tb00438.x.

Cronberg, N., Wyatt, R., Odrzykoski, I.J., Andersson, K. 2005. Genetic diversity of the moss Plagiomnium affine in forests of contrasting age. - Lindbergia, 30(2), 49-58.

Egnell, G. 2011. Is the productivity decline in Norway spruce following whole-tree harvesting in the final felling in boreal Sweden permanent or temporary? - Forest Ecology and Management, 261(1), 148-153. https:// doi.org/10.1016/j.foreco.2010.09.045.

Egnell, G., Jurevics, A., Peichl, M. 2015. Negative effects of stem and stump harvest and deep soil cultivation on the soil carbon and nitrogen pools are mitigated by enhanced tree growth. - Forest Ecology and Management, 338, 57-67. https://doi.org/10.1016/j.foreco.2014.11.006.

Egnell, G., Leijon, B. 1997. Effects of different levels of biomass removal in thinning on short term production of Pinus sylvestris and Picea abies stands. - Scandinavian Journal of Forest Research, 12, 17-26. https://doi. org/10.1080/02827589709355379.

Ellenberg, H. 1988. Vegetation Ecology of Central Europe. $4^{\text {th }}$ Ed. Cambridge, Cambridge University Press. 731 pp. 
Engelmark, O., Hytteborn, H. 1999. Coniferous forests. - Sjögren, E. (ed.). Swedish plant geography. Uppsala, Opulus Press, 55-75.

Grime, J.P. 2006. Plant strategies, vegetation processes and ecosystem properties. Chichester, John Wiley \& Sons Ltd. 456 pp.

Hakkila, P. (ed.). 2004. Developing technology for large-scale production of forest chips. Wood Energy Technology Programme 1999-2003. Helsinki, Tekes. 99 pp.

Hart, S.A., Chen, H.Y.H. 2008. Fire, logging, and overstory affect understory abundance, diversity, and composition in boreal forest. - Ecological Monographs, 78(1), 123-140. https:/ /doi.org/10.1890/06-2140.1.

Hyvönen, R., Kaarakka, L., Leppälammi-Kujansuu, J., Olsson, B.A., Palviainen, M., VegerforsPersson, B., Helmisaari, H.-S. 2016. Effects of stump harvesting on soil $\mathrm{C}$ and $\mathrm{N}$ stocks and vegetation 8-13 years after clear-cutting. Forest Ecology and Management, 371, 23-32. https:/ / doi.org/10.1016/j.foreco.2016.02.002.

Jonsson, B.G., Essen, P.A. 1990. Treefall disturbance maintains high bryophyte diversity in a boreal spruce forest. - Journal of Ecology, 78, 924-936. https:/ / doi.org/10.2307/2260943.

Kneeshaw, D.D., Bergeron, Y. 1998. Canopy gap characteristics and tree replacement in the Southeastern boreal forest. - Ecology, 79(3), 783-794. https://doi.org/10.2307/176578.

Kolstad, A.L., Asplund, J., Nilsson, M.C., Ohlson, M., Nybakken, L. 2016. Soil fertility and charcoal as determinants of growth and allocation of secondary plant metabolites in seedlings of European beech and Norway spruce. - Forest Ecology and Management, 131, 39-46. https://doi.org/10.1016/j. envexpbot.2016.06.013.

Krebs, C.J. 2014. Species diversity measures. Krebs, C.J. (ed.). Ecological methodology. Vancouver, University of British Columbia, 532-593.

Kubin, E. 1983. Nutrients in the soil, ground vegetation and tree layer in an old spruce forest in Northern Finland. - Annales Botanici Fennici, 20(4), 361-390.

Luzuriaga, A.L., Escudero, A., Olano, J.M., Loidi, J. 2005. Regenerative role of seed banks following an intense soil disturbance. - Acta Oecologica, 27(1), 57-66. http://doi.org/10.1016/j. actao.2004.09.003.

Miles, J. 1985. The pedogenic effects of different species and vegetation types and the implications of succession. - Journal of Soil Science, 36(4), 571-584. https://doi. org/10.1111/j.1365-2389.1985.tb00359.x.

Nikodemus, O., Klaviņšs, M., Krišjāne, Z., Zelčs, V. 2018. Latvija. Zeme, Daba, Tauta, Valsts. Rīga, Latvijas Universitātes Akadēmiskais apgāds. 752 pp. (In Latvian).

Nilsson, M.C., Wardle, D.A. 2005. Understory vegetation as a forest ecosystem driver: evidence from the northern Swedish boreal forest. - Frontiers in Ecology and the
Environment, 3(8), 421-428.

Oksanen, J., Blanchet, F.G., Friendly, M., Kindt, R., Legendre, P., McGlinn, D., Minchin, P.R., O'Hara, R.B., Simpson, G.L., Solymos, P., Henry, M., Stevens, H., Szoecs, E., Wagner, H. 2013. Vegan: Community Ecology Package. [WWW document]. - URL http://CRAN.Rproject.org/package=vegan/. [Accessed 27 December 2018]

Packham, J.R. 1978. Biological flora of the British Isles. Oxalis Acetosella L. - Journal of Ecology, 66, 669-693.

R Core Team. 2017. R: A language and environment for statistical computing. $\mathrm{R}$ Foundation for Statistical Computing, Vienna, Austria. [WWW document]. - URL https://www.Rproject.org/. [Accessed 27 December 2018].

Rytter, L., Johansson, K., Karlsson, B., Stener, L.-G. 2013. Tree Species, Genetics and Regeneration for Bioenergy Feedstock in Northern Europe. Kellomäki, S., Kilpeläinen, A., Alam, S. (eds.). Forest BioEnergy Production. New York, Springer, 7-16.

Saetre, P., Saetre, L.S., Brandtberg, P.-O., Lundkvist, H., Bengtsson, J. 1997. Ground vegetation composition and heterogeneity in pure Norway spruce and mixed Norway spruce-birch stands. - Canadian Journal of Forest Research, 27, 2034-2042. https://doi. org/10.1139/ x97-177.

Saksa, T. 2013. Regeneration after stump harvesting in southern Finland. - Forest Ecology and Management, 290, 79-82. https:/ / doi.org/10.1016/j.foreco.2012.08.014.

Sirén, M. 1955. The development of spruce forest on raw humus sites in Northern Finland and its ecology. - Acta Forestalia Fennica, 62(4), 1-408. https://doi.org/10.14214/aff.7453.

Uotila, A., Kouki, J. 2005. Understorey vegetation in spruce-dominated forests in eastern Finland and Russian Karelia: Successional patterns after anthropogenic and natural disturbances. - Forest Ecology and Management, 215(13), 113-137. https://doi.org/10.1016/j. foreco.2005.05.008.

Vanha-Majamaa, I., Shorohova, E., Kushnevskaya, H., Jalonen, J. 2017. Resilience of understory vegetation after variable retention felling in boreal Norway spruce forests - A tenyear perspective. - Forest Ecology and Management, 393, 12-28. https://doi. org/10.1016/j.foreco.2017.02.040.

Vellak, K., Paal, J., Liira, J. 2003. Diversity and distribution pattern of bryophytes and vascular plants in a boreal spruce forest. - Silva Fennica, 37(1), 3-13. https://doi.org/10.14214/sf.508.

Walmsley, J.D., Jone, D.L., Reynolds, B., Price, M.H., Healey, J.R. 2009. Whole tree harvesting can reduce second rotation forest productivity. - Forest Ecology and Management, 257(3), 1104-1111. foreco.2008.11.015. 